\title{
Mitochondrial evidence supports a Nearctic origin for the spreading limicolous earthworm Sparganophilus tamesis Benham, 1892 (Clitellata, Sparganophilidae)
}

\author{
Emilia Rota ${ }^{1,6}$, Svante Martinsson ${ }^{2}$, Marco Bartoli $^{3}$, Anneke Beylich ${ }^{4}$, Ulfert Graefe ${ }^{4}$, Alex Laini ${ }^{3}$, Mark J. Wetzel ${ }^{5}$, \\ Christer Erséus ${ }^{2}$ \\ ${ }^{1}$ Department of Physics, Earth and Environmental Sciences, University of Siena, Via P.A. Mattioli 4, IT-53100 \\ Siena, Italy \\ ${ }^{2}$ Department of Biological and Environmental Sciences, University of Gothenburg, Box 463, SE-405 30 Göteborg, \\ Sweden \\ ${ }^{3}$ Department of Life Sciences, University of Parma, Parco Area delle Scienze 11/A, IT-43124 Parma, Italy \\ ${ }^{4}$ IFAB Institute for Applied Soil Biology, Tornberg 24a, 22337 Hamburg, Germany \\ ${ }^{5}$ Illinois Natural History Survey (INHS), Prairie Research Institute at the University of Illinois at Urbana- \\ Champaign, Forbes Natural History Bldg., 1816 South Oak St., Champaign, Illinois 61820 USA \\ ${ }^{6}$ E-mail: rota@unisi.it
}

Key words: aquatic megadriles, genetic divergence, Oligochaeta, recent introduction, Sparganophilus eiseni, synonymy

\begin{abstract}
We analysed samples of Sparganophilus taken at the corners of its distribution area in Europe (UK, Germany and Italy). No mitochondrial genetic divergence within and amongst them was found, neither in COI nor in 16S. Further, the COI haplotype was also identical to two sequences from Ontario, Canada in the Barcoding of Life Data System (BOLD) database. Our European $\mathrm{COI}$ and $16 \mathrm{~S}$ sequences showed only minimal differentiation (only 1 or 2 substitutions) from specimens newly collected in Illinois and Washington states (USA), as well as from a COI haplotype from Tennessee (USA) in BOLD. An additional COI haplotype from Illinois (found in BOLD) is $2.1 \%$ different from the other haplotypes but clearly belongs to the same lineage of Sparganophilus. This geographically broad but genetically compact group fits the morphological diagnosis of S. tamesis Benham, 1892 as revised by Jamieson (1971) and is seen as evidence that all European populations 1) belong to the same species, 2) derive from a recent introduction, 3) are conspecific with the most widespread species of Sparganophilus in North America, and that 4) S. tamesis is a senior synonym of $S$. eiseni Smith, 1895. The single European haplotype does not refute the possibility of its spread from a single introduced source population.
\end{abstract}

\section{Contents}

Introduction 113

Material and methods ….................................................. 115

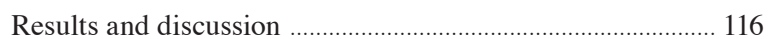

Acknowledgements ................................................................ 118

References

\section{Introduction}

The aquatic megadrile Sparganophilus tamesis Benham, 1892 (type species of the monotypic Sparganophilidae) was first discovered in River Thames south of Oxford, England, hence the type species name. However, in his description of this species, Benham suggested that cocoons may have been an introduction from North America, via the roots of water plants or attached to timber that had been shipped from the United States (Benham, 1892: p. 175; see Rota et al., 2014). The taxon was never recorded again in Europe until Černosvitov (1945), based on a rich collection of specimens from Windermere, England, pointed out possible errors in the original description - which might have led to misinterpretations and descriptions of synonyms such as Pelodrilus cuenoti Tétry, 1934 from France (see full list of synonyms in Rota et al., 2014). In particular, the interchaetal dorsal interval $d d$, illustrated by Benham (1892) as broader than half the body circumference, differed by being one-third the body circumference in the worms studied by Tétry (1934) and Černosvitov (1945).

In the meantime, Sparganophilus Benham, 1892 had been found also in North and Central America. Trusting Benham's account of S. tamesis (ventral position of the outer chaetae and lack of prostate-like glands), three new congeners had been described: one from Illinois, USA (S. eiseni Smith, 1895), and two 


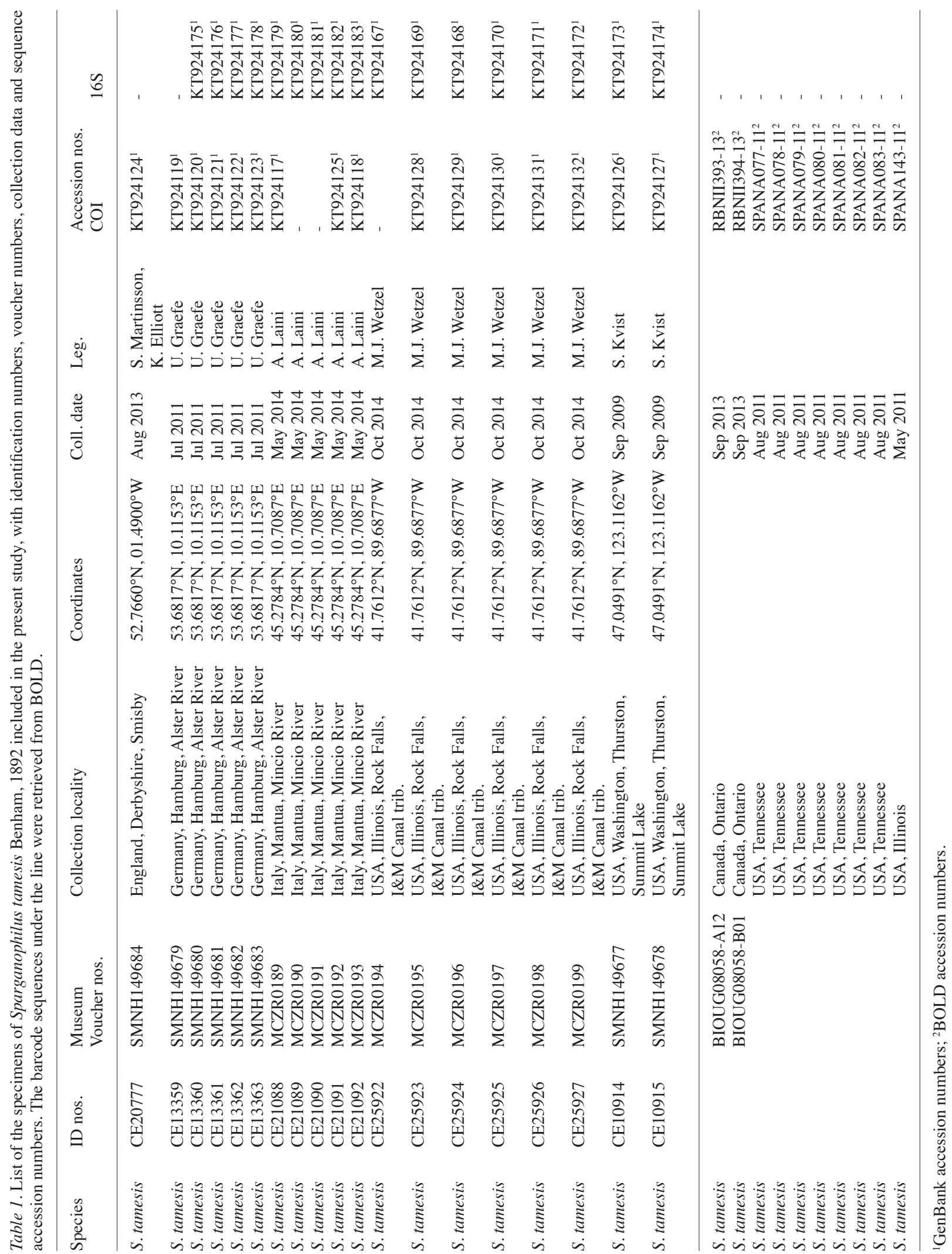


more from California, Mexico and Guatemala ( $S$. smithi Eisen, 1896 and S. benhami Eisen, 1896). Additional collections had soon extended the distribution of $S$. eiseni to Ohio, Michigan, Florida, Indiana and Canada (e.g., Smith, 1896; Moore, 1906; Heimburger, 1915). Michaelsen (1918) refuted Moore's (1895) identifications of S. tamesis from Pennsylvania and New Jersey - suggesting instead that this species was a European autochthon.

Černosvitov (1945), considering the large range of distribution of S. tamesis in England, its occurrence in France and its absence in America, suggested that the genus' distribution should be explained by the past geological relationships between the American and European continents rather than by accidental importation. Omodeo (1963) followed the trail and hypothesized that a Sparganophilus ancestor reached Europe from North America via a land-bridge across the Atlantic in a relatively ancient age, evolving to the European endemic S. tamesis.

Jamieson (1971), upon re-examination of the typespecimens of S. tamesis, left no morphological grounds for the distinction of North American S. eiseni - either as a specific or an infraspecific taxon - and considered the occurrence of S.tamesis at Kew Gardens as further support for the hypothesis of human transportation. To Gates (1982) it seemed a 'plausible view that sparganophilids were taken to England since 1500 A.D. and unwittingly by man', and Sims and Gerard (1985) concurred: 'as the British records can all be associated with gardens containing imported aquatic plants, e.g., Goring-on-Thames, the type locality, is only a few miles downstream from the Botanic Gardens, Oxford'. Zicsi and Vaucher (1987) agreed on the proposed synonymy of S. eiseni with S. tamesis and could not see any other explanation for its occurrence in Europe (including their new record from Switzerland) than transplantation of aquatic plants from North America to England, and from there throughout the old continent. However, Reynolds (e.g., 1980, 1995, 2008) has always maintained the synonymy of $S$.tamesis with S. eiseni to be unacceptable, claiming to have identified both species in specimens deposited in the Natural History Museum (London) that had been collected from artificial water habitats in England.

More recently, Bouché and Qiu (1998) have revived the view of the Sparganophilidae as a family suggestive of earlier connections between the two continents, and have even hypothesized the presence in Europe of two endemic species: the more widespread S. tamesis, postglacially re-expanded north of the Alps, and the
Swiss S. langi Bouché and Qiu, 1998, which survived in the Rhone-Ebro basin during the glaciations and afterwards recolonized part of the Mediterranean. On the other hand, molecular phylogenetics (Jamieson et al., 2002; James and Davidson, 2012) indicates that the family Sparganophilidae is sister taxon to Komarekionidae, a monospecific earthworm family living in forest soils in midwestern (Illinois, Indiana, Kentucky) and eastern United States (Georgia through Maryland) in and adjacent to the Appalachian Highlands region (Reynolds and Wetzel, 2008; Rota et al., 2014a; Rota and de Jong, 2015).

Stimulated by the recent discovery of well-established populations of Sparganophilus in Germany (Graefe and Beylich, 2011) and Italy (Rota et al., 2014) - in both cases morphologically conforming to the diagnosis of S. tamesis as revised by Jamieson (1971) we analysed the mitochondrial genetic diversity (COI and 16S) of samples of Sparganophilus from the extreme corners (UK, Germany and Italy) of its distribution area in Europe (see map in Rota et al., 2014: fig. 3) and from two well separated locations in the United States, one of which not far from the type locality of $S$. eiseni. The newly obtained COI sequences were compared to barcode sequences of North American Sparganophilus available in BOLD (Barcoding of Life Data Systems; Ratnasingham and Hebert, 2007), with the aims to find: molecular evidence on the identity/ separation between S. tamesis and S. eiseni, arguments favouring/disproving recent introduction over old endemic distribution, and information about the possible provenience of the European specimens.

\section{Material and methods}

Nineteen newly-sequenced specimens of Sparganophilus tamesis from three European (England, Germany and Italy) and two North American (Illinois and Washington states) populations (see Table 1 for details) were included in the study. The morphology of adults from Italy, Germany and Illinois fits the diagnosis of $S$. tamesis by Benham (1892) as revised by Jamieson (1971). For a detailed morpho-anatomical study of the Italian worms see Rota et al. (2014). The specimens from England and Washington were immature and were identified through DNA barcoding. DNA was extracted from a piece of body wall from the posterior region of the worms. The extractions were performed with either Qiagen's DNeasy Blood \& Tissue Kit or Epicentre QuickExtract DNA Extraction Solution 1.0, 
following the manufacturer's instructions. Parts of two mitochondrial markers, 16S ribosomal RNA (16S), and cytochrome c oxidase subunit I (COI), were amplified. 16S was amplified using the primers AnnF and AnnR (Sjölin et al., 2005), and the following program: $95^{\circ} \mathrm{C}$ for $5 \mathrm{~min}$, followed by 35 cycles of $95^{\circ} \mathrm{C}$ for $30 \mathrm{~s}$, $45^{\circ} \mathrm{C}$ for $30 \mathrm{~s}$ and $72^{\circ} \mathrm{C}$ for $1 \mathrm{~min}$ and a final extension step at $72^{\circ} \mathrm{C}$ for $8 \mathrm{~min}$; COI using the primers LCO1490 and HCO2198 (Folmer et al., 1994) or COI-E (Bely and Wray, 2004), and the following program: $95^{\circ} \mathrm{C}$ for $5 \mathrm{~min}$, followed by 35 cycles of $95^{\circ} \mathrm{C}$ for $40 \mathrm{~s}, 45^{\circ} \mathrm{C}$ for $45 \mathrm{~s}$ and $72^{\circ} \mathrm{C}$ for $1 \mathrm{~min}$ and a final extension step at $72^{\circ} \mathrm{C}$ for $8 \mathrm{~min}$. After amplification, existence of the target genes was confirmed using $1 \%$ agarose gel electrophoresis. PCR products were purified using exonuclease I (Fermentas, Burlington, Canada) and FastAP thermosensitive alkaline phosphatase (Fermentas) (Werle et al., 1994) following the protocol provided by the producer (Fermentas, Burlington, Canada). Sequencing was performed by Macrogen Inc. (Seoul, Korea) and Eurofins MWG Operon (Ebersberg, Germany). Sequences were assembled and trimmed to the same length (334 bp for $16 \mathrm{~S}$ and $531 \mathrm{bp}$ for COI) in GENEIOUS PRO v. 7.1 (Biomatters Ltd., Auckland, New Zealand). Ten additional COI sequences belonging to $S$. tamesis were found in the BOLD database (accessed 12 Oct 2015) by using one of our COI sequences as query for an identification request. The BOLD sequences were labelled as Sparganophilus from Ontario (Canada) or as unspecified Haplotaxida from Illinois and Tennessee (USA), and belong to BIN BOLD:ABA8326 (BINs are clusters of close barcode sequences that are assumed to correspond to species; Ratnasingham and Hebert, 2013), and we included them in our COI dataset. Sequences were aligned using MAFFT v7.017 (Katoh et al., 2002) as implemented in Geneious using the auto algorithm.
Haplotype networks were constructed for both genes in PopART v1 (Leigh and Bryant, 2015) using statistical parsimony (Templeton et al., 1992; Clement et al., 2002).

We also compared our $16 \mathrm{~S}$ and COI data to the data in GenBank by performing BLAST (Altschul et al., 1990) searches; the searches were performed as Standard Nucleotide BLAST (blastn) against the Nucleotide collection (nr/nt) database using Megablast (http://blast. ncbi.nlm.nih.gov/Blast.cgi; accessed 12 Oct 2015).

The low mitochondrial divergence (see Results and discussion section) made us decide not to include any nuclear markers, as even a fast evolving marker such as ITS has less or the same amount of variation as COI, at least in clitellates (e.g. De Wit and Erséus, 2010; Martinsson et al., 2013; Timm et al., 2013).

All new 16S sequences and COI barcodes are deposited in GenBank (Table 1). Voucher specimens as well as non-sequenced specimens from the same localities are deposited in the Museo Civico di Zoologia di Roma, Italy (MCZR), and the Swedish Museum of Natural History, Stockholm (SMNH) (Table 1). Additional reference specimens from the studied sites are deposited in the Illinois Natural History Survey (INHS) Annelida Collection, Champaign, Illinois, USA, and the Zoological Museum Hamburg, Germany (ZMH).

\section{Results and discussion}

COI was successfully sequenced from 16 individuals, representing all populations sampled by us, and - with the 10 additional specimens retrieved from BOLD the COI dataset comprised 26 sequences; whereas we obtained $16 \mathrm{~S}$ sequences from 17 individuals from four of the five included populations, as we failed to amplify $16 \mathrm{~S}$ from the individual from England. In GenBank we

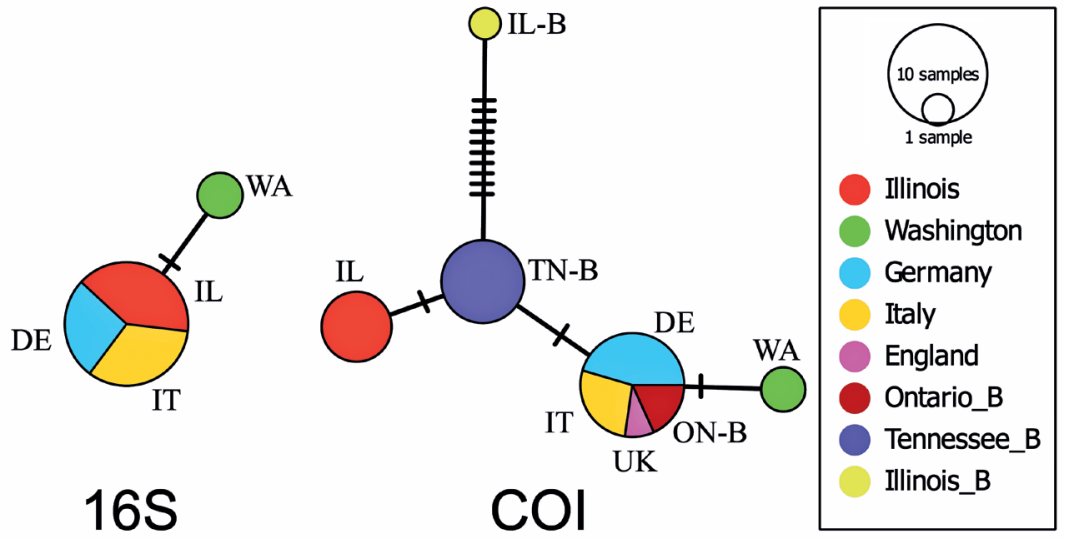

Fig. 1. Haplotype networks illustrating the patterns of divergence of the sampled populations of Sparganophilus tamesis Benham, 1892 from Illinois and Washington states (USA), Germany, Italy, and England based on $16 \mathrm{~S}$ and COI sequences. In the COI network, additional North American specimens retrieved from BOLD as belonging to the same barcode cluster are included. The colours represent geographical origin; localities followed by 'B' indicate BOLD data. Hatch marks correspond to nucleotide substitutions. 
found no sequences of $\mathrm{COI}$ or $16 \mathrm{~S}$ that were close to our $S$. tamesis sequences.

In the gathered dataset genetic variation is low and all individuals clearly belong to the same species. In the newly sequenced material we found 3 COI haplotypes, separated by 1-3 substitutions: one in each of our American populations (from the states of Illinois and Washington, USA) and one shared by all the European worms. With the sequences from BOLD, the number of haplotypes increased to 5 , with one additional haplotype from Illinois and one from Tennessee, while the sequences from Ontario, Canada belong to the same haplotype as our European specimens. The Illinois haplotype from BOLD differs by 10-12 substitutions from the other haplotypes, which differ from each other by only 1-3 substitutions. For $16 \mathrm{~S}$, in our material we found 2 haplotypes, separated by one substitution, one unique for the population from Washington and one shared between the European populations and the population from Illinois (see Fig. 1).

We found no mitochondrial genetic divergence among the European populations, and only a minimum differentiation from the specimens newly collected in Illinois and Washington states (1 or 2 substitutions in the COI gene, 0 or 1 substitution in the 16S gene, respectively), as well as from the specimens from Tennessee and Ontario retrieved from BOLD (0-1 substitutions in COI). The additional haplotype from Illinois is more distant (11 substitutions), but still closely related ( $2.1 \%$ different) to the others. This geographically broad but genetically compact group fits the morphological diagnosis of S. tamesis as revised by Jamieson (1971) and is seen as evidence that all European populations: 1) belong to the same species, 2) derive from a recent introduction, and 3) are conspecific with the most widespread and northerly expanded lineage of Sparganophilus in North America (sampled from sites as far apart as Ontario, Tennessee, Illinois, and Washington) as the worm commonly referred to as ' $S$. eiseni' should be; and that 4) S. tamesis is a senior synonym of S. eiseni. All other North American Sparganophilus sequences recorded in BOLD fall into clusters that are well separated from $S$. tamesis. In GenBank, 16S sequences of other unidentified species of Sparganophilus were found, the closest being 7\% different from S. tamesis.

Our new North American samples were collected from two well-separated localities (Table 1). The Illinois site $-160 \mathrm{~km}$ to the NNE of the type locality of $S$. eiseni (north of Havana, in Mason County) - is located near the town of Rock Falls in Whiteside County, along a small tributary of the Illinois and Mississippi (I \& M) Canal, which flows NNE for $3 \mathrm{~km}$ before its confluence with the Rock River. Both the Rock and Illinois rivers drain into the Mississippi River, although their confluences are located 420 river $\mathrm{km}$ apart. According to Reynolds and Wetzel (2011: p. 62), 'S. eiseni' is the only species in the family known to occur in Illinois.

Our locality in the state of Washington, USA is on the southern bank of Summit Lake in Thurston County (just west of the city of Olympia) (Table 1); this site is $2741 \mathrm{~km} \mathrm{WNW}$ of the $S$. eiseni type locality near Havana, Illinois, and $2700 \mathrm{~km} \mathrm{WNW}$ of the site at Rock Falls, Illinois. Summit Lake is oligotrophic, characterized by low nutrient levels, low algae growth, and good water clarity. Land uses are commercial forest and dense residential development (approximately 400 homes) along the shoreline. Primary water uses are domestic water supply, fishing, boating, swimming, and other water sports - none of which are impeded by aquatic weeds or algal growth; water quality is classified as excellent (http://www.co.thurston.wa.us/health/ ehadm/swimming/SummitLake.html). Thus the new site does not seem affected by invasions of alien aquatic plants, as many other places in the Pacific Northwest (http://www.ecy.wa.gov/programs/eap/lakes/aquaticplants/index.html\#annualsurvey). In any case, the low genetic divergence from the eastern American samples (new and in BOLD) would suggest that this population is of recent introduction.

For some reason, the two previous records of Sparganophilus (juvenile specimens) reported from the state of Washington (Reynolds, 1980: 'Jefferson Co., Kalaloch, near lake Crescent'; and 'Pacific Co., South bend of Tokeland'), and the collections of juveniles in southern Alaska (S of Ketchican) and northern British Columbia (E of Prince Rupert Island) (Reynolds, 1980), were not mentioned later when Reynolds (2008) revisited the North American distribution of the family. Altman (1936) did not mention Sparganophilidae in his monograph on the Oligochaeta of Washington. Our new locality of $S$. tamesis in the state of Washington confirms the occurrence of these worms north of Oregon and hints at the possibility that they presently may be as well represented in suitable substrates in the $\mathrm{Pa}$ cific Northwest as they are in those of the Atlantic Maritime region of Canada (McAlpine et al., 2001).

The single European COI haplotype does not refute the possibility of a spread throughout the old continent from a single introduced source population, as suggested by Zicsi and Vaucher (1987) and Rota et al. 
(2014). Interestingly, in Europe Sparganophilus cocoons have thus far been recovered only from amongst the roots of Sparganium ramosum Huds. (= erectum L.) (Benham 1892), Sagittaria sagittifolia L. (Benham, 1892: p. 156, footnote 2), and Vallisneria spiralis L. (Rota et al., 2014) - all aquatic plants with tape-like submerged foliage. These plant species also share the morphology of the root, comprising a mass of tiny root hairs (and not a single rhizome) among which cocoons can be laid and anchored. Furthermore, by leaking photosynthetically produced oxygen (e.g., Soana and Bartoli, 2013), the roots of these plants create an oxic rhizosphere, which makes sediments less inhospitable for the worm's eggs and hatchlings (Rota et al., 2014). Sagittaria is also present in the Alster site near Hamburg, Germany (U. Graefe, pers. obs.), and in the Rock Falls site, Illinois, USA (M.J. Wetzel, pers. obs.). It does appear, however, that - at least in North America - the habitats of reproduction of S. tamesis are more diverse (e.g., Harman, 1965). Within the limits of our sampling, the identity of the $16 \mathrm{~S}$ sequences points towards the Illinois samples being part of the pool from which the worms introduced to Europe originated. However, the DNA data indicate that neither of our two sampled American populations are the source of the introduction. With better sampling across the geographical range of this species, perhaps combined with the use of a faster evolving marker, e.g., microsatellites (Cristescu, 2015), it may be possible to find the source population, or at least define a smaller area from where the introduction originated. However, since the European COI haplotype is identical with sequences from Ontario found in BOLD, it seems likely that the European populations have their origin somewhere in the northern part of the species' North American distribution.

\section{Acknowledgements}

We thank Sebastian Kvist for collecting the Washington material, Kerryn Elliott for assisting in field work in England, and Urban Olsson, Marcus Svensson and Mårten Eriksson for lab work at various times. The helpful remarks and suggestions from three anonymous reviewers are also thankfully acknowledged. Financial support was given to S.M. by Adlerbertska Stipendiefonden and Paul och Marie Berghaus Stipendiefond, to C.E. by the Swedish Research Council, and to M.J.W. by the Illinois Natural History Survey (INHS) and anonymous benefactors.

\section{References}

Altman LC. 1936. Oligochaeta of Washington. University of Washington Publications in Biology 4: 1-137.

Bely AE, Wray GA. 2004. Molecular phylogeny of naidid worms (Annelida: Clitellata) based on cytochrome oxidase I. Molecular Phylogenetics and Evolution 30: 50-63.

Benham WB. 1892. A new English genus of aquatic Oligochaeta (Sparganophilus) belonging to the family Rhinodrilidae. Quarterly Journal of Microscopical Science (n.s.) 34: $155-179$.

Bouché MB, Qiu J-P. 1998. Un nouveau Sparganophilus (Annelida: Oligochaeta) d'Europe, avec considérations paléogéographiques sur les Lumbricina. Documents pédozoologiques et intégrologiques 4: 178-180.

Černosvitov L. 1945. Oligochaeta from Windermere and the Lake District. Proceedings of the Zoological Society of London 114: 523-548.

Clement M, Snell Q, Walke P, Posada D, Crandall K. 2002. TCS: estimating gene genealogies. Proceedings of the 16th International Parallel and Distributed Processing Symposium 2: 184.

Cristescu ME. 2015. Genetic reconstructions of invasion history. Molecular Ecology 24: 2212-2225.

de Wit P, Erséus C. 2010. Genetic variation and phylogeny of Scandinavian species of Grania (Annelida: Clitellata: Enchytraeidae), with the discovery of a cryptic species. Journal of Zoological Systematics and Evolutionary Research 48: 285-293.

Eisen G. 1896. Pacific Coast Oligochaeta. II. Memoirs of the California Academy of Sciences 2: 123-199.

Folmer O, Black M, Hoeh W, Lutz R, Vrijenhoek R. 1994. DNA primers for amplification of mitochondrial cytochrome $\mathrm{c}$ oxidase subunit I from diverse metazoan invertebrates. Molecular Marine Biology and Biotechnology 3: 294-299.

Gates GE. 1982. Farewell to North American megadriles. Megadrilogica 4: 12-77.

Graefe U, Beylich A. 2011. First record of the aquatic earthworm Sparganophilus tamesis Benham, 1892 (Clitellata, Sparganophilidae) in Germany. Abstracts of the 5th International Oligochaete Taxonomy Meeting, Beatenberg, Switzerland: 25 .

Harman WJ. 1965. Life history studies of the earthworm Sparganophilus eiseni in Louisiana. The Southwestern Naturalist 10: 22-24.

Heimburger HV. 1915. Notes on Indiana earthworms. Proceedings of the Indiana Academy of Sciences 25: 281-285.

James S, Davidson S. 2012. Molecular phylogeny of earthworms (Annelida: Crassiclitellata) based on 28S, 18S and 16S gene sequences. Invertebrate Systematics 26: 213-229.

Jamieson BGM. 1971. Family Glossoscolecidae. Pp. 723-837 in: Brinkhurst RO, Jamieson BGM, eds, Aquatic Oligochaeta of the World. Edinburgh, UK: Oliver \& Boyd.

Jamieson BG, Tillier S, Tillier A, Justine J, Ling E, James S, McDonald K, Hugall AF. 2002. Phylogeny of the Megascolecidae and Crassiclitellata (Annelida, Oligochaeta): combined versus partitioned analysis using nuclear (28S) and mitochondrial (12S, 16S) rDNA. Zoosystema 24: 707-734.

Katoh K, Misawa K, Kuma K, Miyata T. 2002. MAFFT: a novel method for rapid multiple sequence alignment based on fast Fourier transform. Nucleic Acids Research 30: 30593066. 
Leigh JW, Bryant D. 2015. POPART: full-feature software for haplotype network construction. Methods in Ecology and Evolution 6: 1110-1116.

Martinsson S, Achurra A, Svensson M, Erséus C. 2013. Integrative taxonomy of the freshwater worm Rhyacodrilus falciformis s.l. (Clitellata: Naididae), with the description of a new species. Zoologica Scripta 42: 612-622.

McAlpine DF, Reynolds JW, Fletcher TJ, Trecartin JL, Sabine DL. 2001. Sparganophilus eiseni (Oligochaeta, Sparganophilidae) in New Brunswick, an addition to the earthworm fauna of Maritime Canada. Megadrilogica 8: 53-56.

Michaelsen W. 1918. Die Lumbriciden, mit besonderer Berücksichtigung der bisher als Familie Glossoscolecidae zusammengefassten Unterfamilien. Zoologische Jahrbücher, Abtheilung für Systematik 41: 1-398.

Moore HF. 1895. On the structure of Bimastos palustris, a new oligochaete. Journal of Morphology 10: 473-496.

Moore HF. 1906. Hirudinea and Oligochaeta collected in the Great Lakes region. Bulletin of the Bureau of Fisheries 25: 153-171.

Omodeo P. 1963. Distribution of the terricolous oligochaetes on the two shores of the Atlantic. Pp. 128-151 in: Löve A, Löve D, eds, North Atlantic Biota and their History. Oxford, UK: Pergamon Press.

Ratnasingham S, Hebert PD. 2007. BOLD: The Barcode of Life Data System (http://www.barcodinglife.org). Molecular Ecology Notes 7: 355-364.

Ratnasingham S, Hebert PD. 2013. A DNA-based registry for all animal species: the barcode index number (BIN) system. PLOS ONE 8: e66213.

Reynolds JW. 1980. The earthworm family Sparganophilidae (Annelida, Oligochaeta) in North America. Megadrilogica 3: 189-204.

Reynolds JW. 1995. The distribution of earthworms (Annelida, Oligochaeta) in North America. Pp. 133-153 in: Mishra PC, Behera N, Senapati BK, Guru BC, eds, Advances in Ecology and Environmental Sciences. New Delhi, India: Ashish Publ. House.

Reynolds JW. 2008. Sparganophilidae (Annelida, Oligochaeta) distribution in North America and elsewhere, revisited. Megadrilogica 12: 125-143.

Reynolds JW, Wetzel MJ. 2008. Terrestrial Oligochaeta (Annelida: Clitellata) in North America, including Mexico, Puerto Rico, Hawaii, and Bermuda. Megadrilogica 12: 157-208.

Reynolds JW, Wetzel MJ. 2011. The earthworms (Oligochaeta: Acanthodrilidae, Glossoscolecidae, Komarekionidae, Lumbricidae, Megascolecidae, and Sparganophilidae) of Illinois, USA. Megadrilogica 15: 35-67.
Rota E, Bartoli M, Laini A. 2014. First time in Italy. Is the elusive aquatic megadrile Sparganophilus Benham, 1892 (Annelida, Clitellata) accelerating its dispersal in Europe? Journal of Limnology 73: 482-489.

Rota E, de Jong Y. 2015. Fauna Europaea: Annelida - Terrestrial Oligochaeta (Enchytraeidae and Megadrili), Aphanoneura and Polychaeta. Biodiversity Data Journal 3 (e5737): 1-48.

Sims RW, Gerard BM. 1985. Earthworms. Synopses of the British Fauna (New Series), No. 31. London, UK: Linnean Society of London, The Estuarine and Coastal Sciences Association and Field Studies Council. (Revised in 1999).

Sjölin E, Erséus C, Källersjö M. 2005. Phylogeny of Tubificidae (Annelida, Clitellata) based on mitochondrial and nuclear sequence data. Molecular Phylogenetics and Evolution 35: 431-441.

Smith F. 1895. A preliminary account of two new Oligochaeta from Illinois. Bulletin of the Illinois State Laboratory of Natural History 4: 138-147.

Smith F. 1896. Notes on species of North American Oligochaeta. II. Bulletin of the Illinois State Laboratory of Natural History 4: 396-413.

Soana E, Bartoli M. 2013. Seasonal variation of radial oxygen loss in Vallisneria spiralis L.: An adaptive response to sediment redox? Aquatic Botany 104: 228-232.

Templeton AR, Crandall KA, Sing CF. 1992. A cladistic analysis of phenotypic associations with haplotypes inferred from restriction endonuclease mapping and DNA sequence data. III. Cladogram estimation. Genetics 132: 619-633.

Tétry A. 1934. Description d'une espèce française du genre Pelodrilus. Comptes rendus hebdomadaires des séances de l’Académie des Sciences 199: 322-324.

Timm T, Arslan N, Rüzgar M, Martinsson S, Erséus C. 2013. Oligochaeta (Annelida) of the profundal of Lake Hazar (Turkey), with description of Potamothrix alatus hazaricus n. ssp. Zootaxa 3716: 144-156.

Werle E, Schneider C, Renner M, Volker M, Fiehn W. 1994. Convenient single-step, one tube purification of PCR products for direct sequencing. Nucleic Acids Research 22: 4354-4355.

Zicsi A, Vaucher C. 1987. A propos de la présence de Sparganophilus tamesis Benham dans le lac Léman à Genève (Oligochaeta: Sparganophilidae). Revue Suisse de Zoologie 94: 861-864.

Received: 19 May 2015

Revised and accepted: 28 October 2015

Published online: 9 March 2016

Editor: R. Sluys 